\title{
Linkage analysis of French families with facioscapulohumeral muscular dystrophy
}

\author{
G LUCOTTE*, S BERRICHE*, AND M FARDEAU† \\ From *the Laboratory of Physical Anthropology, Collège de France, Paris 5ème; and the Laboratory of \\ Neuromuscular Biology and Pathology, INSERM U 153, Paris 5ème, France.
}

SUMMARY Linkage analysis was undertaken in seven French families with facioscapulohumeral muscular dystrophy (FSHD). Six polymorphic DNA probes were studied, including random DNA sequences, coding sequences, and a hypervariable marker. No evidence for linkage of these probes to the disease was detected, and the results exclude probable location of the FSHD gene from three chromosomal regions (16p, proximal 19q, and $21 q)$.

Facioscapulohumeral muscular dystrophy (FSHD) is a relatively common autosomal dominant neuromuscular disorder. ${ }^{1}$ The onset of symptoms is usually at the end of the first decade or in the second. ${ }^{2}$ Presenting signs include weakness of facial muscles and weakness and atrophy of shoulder girdle muscles, often with subsequent spread to muscles of the upper arm and to the extensors of the foot. ${ }^{3}$ Asymmetrical muscle involvement occurs frequently, and the rate of progression is variable. Asymptomatic cases are common at any age.

Padberg et $a l^{4}$ studied 62 affected and 58 unaffected members of 10 FSHD kindreds using 35 different genetic markers. A maximum lod score of 1.428 at a recombination fraction of 0.2 suggested possible linkage with the locus for the constant region of the heavy chains of IgG immunoglobulins $(\mathrm{Gm})$, located on the long arm of chromosome 14 (band $14 \mathrm{q} 32$ ). Recombination between the disease gene and markers $G m$ and $\alpha_{1}$ antitrypsin was subsequently found from both protein and DNA studies in three large French FSHD families. ${ }^{5}$ Furthermore, in the one large family contributing most to the original positive lod score with $\mathrm{Gm}$, no linkage was found between the disease locus and the probe D14S1, ${ }^{6}$ suggesting that the locus for FSHD is not located on the distal long arm of chromosome 14 .

We have therefore tested a further six polymorphic DNA markers in seven French FSHD families as part of the international collaborative effort to locate the disease gene.

\section{Materials and methods}

From DNA samples obtained from the three families

Received for publication 10 February 1989. Accepted for publication 20 February 1989. examined previously ${ }^{5}$ and from four additional three generation French FSHD kindreds, we have characterised the segregation of restriction fragment length polymorphisms using six DNA probes. Only those sibs that were personally examined by one of us (MF), and who were old enough to be diagnosed as affected or unaffected, were included in the analysis. A total of 75 subjects (22 affected) was sampled, giving 45 potentially informative meioses. DNA isolation, blotting, and hybridisation were as described previously. ${ }^{5}$ The probes used were from chromosomes 16, 19, and 21 (table) and included genomic probes (APOC2, C3, $\beta$ amyloid), anonymous DNA sequences (D21S3, D21S11), and the hypervariable sequence $3^{\prime}$ to the $\alpha$ globin gene (3' $\alpha$ HVR).

Likelihood computations were performed using a modification of the LINKAGE program. ${ }^{7}$ Rapid computation of lod scores for the hypervariable sequence, which has numerous alleles, was facilitated by recoding the genotypes of some subjects so that, at maximum, seven alleles were used.

TABLE Lod scores for linkage between FSHD and six polymorphic DNA probes.

\begin{tabular}{lllllll}
\hline Probe & $\begin{array}{l}\text { Chromosomal } \\
\text { localisation }\end{array}$ & \multicolumn{4}{l}{$\begin{array}{l}\text { Lod score (Z) at recombination } \\
\text { fraction }(\theta)\end{array}$} \\
\cline { 2 - 7 } & & 0.01 & 0.05 & 0.10 & 0.20 & 0.30 \\
\hline 3' $\alpha$ HVR $^{\prime}$ & 16pter-p13 & -19.11 & -11.49 & -7.48 & -3.61 & -1.67 \\
C3 & 19p13.3-p13.2 & -1.44 & -0.88 & -0.38 & -0.25 & -0.03 \\
APOC2 & 19cen-q13.2 & -2.16 & -1.33 & -0.58 & -0.35 & -0.05 \\
D21S11 & 21q11.2-q21 & -1.18 & -0.67 & -0.25 & -0.09 & -0.02 \\
$\beta$ amyloid & 21q21 & -1.44 & -0.88 & -0.38 & -0.25 & -0.03 \\
D21S3 & 21q22.3 & -1.44 & -0.88 & -0.38 & -0.25 & -0.03 \\
\hline
\end{tabular}




\section{Results}

The lod scores at recombination fractions from 0.01 to $\mathbf{0 . 3}$ are shown in the table.

\section{Discussion}

No evidence for linkage of any of the probes tested to the FSHD gene was obtained. Use of the hypervariable probe ( $\left.3^{\prime} \alpha H V R\right)$ has excluded a large subtelomeric region on the short arm of chromosome 16 as a site for probable location of the FSHD gene. Location of FSHD in the centromeric region of chromosome 19 or on the long arm of chromosome 21 is also unlikely. Future work will concentrate on the use of probes located on chromosomes 11 and 1. The exclusion map published in this issue (Sarfarazi et al) will facilitate the search for the location of the FSHD gene.

We would like to thank Veronique Ortéga for assistance in obtaining the family material; Dr A Gal for assistance with the hybridisations using $3^{\prime}$ aHVR; and Dr Clerget for advice on the LINKAGE program. This work was supported by. grants from the Association Française contre les Myopathies.

\section{References}

1 Sorrel-Déjérine Y, Fardeau M. Naissance et métamorphoses de la myopathie atrophique progressive de Landouzy et Déjérine. Rev Neurol (Paris) 1982;138:1041-51.

${ }^{2}$ Padberg G. Facioscapulohumeral disease. Thesis, Leyden University, 1982.

${ }^{3}$ Walton JN, Gardner-Medwin D. Progressive muscular dystrophy and the myotonic disorders. In: Walton JN, ed. Disorders of voluntary muscle. 4th ed. Edinburgh: Churchill Livingstone, 1981:484-524.

4 Padberg G, Eriksson AW, Volkers WS, et al. Linkage studies in autosomal dominant facioscapulohumeral muscular dystrophy. J Neurol Sci 1984;65:261-8.

5 Berriche S, Guettari N, Intrator S, Fardeau M, Lucotte G. Le locus de susceptibilité à la dystrophie musculaire facio-scapulo humérale n'est pas lié à celui des chaînes lourdes d'immunoglobulines. Biosciences (in press).

6 Padberg G, Klasen EC, Wolkers WS, De Lange GG, Wintzen AR. Linkage studies in facioscapulohumeral muscular dystrophy. Muscle Nerve 1988;11:833-5.

${ }^{7}$ Lathrop GM, Lalouel JM, Julier C, Ott J. Multilocus linkage analysis in humans: detection of linkage and estimation of recombination. Am J Hum Genet 1985;37:482-98.

Correspondence to Dr Gerard Lucotte, Laboratoire d'Anthropologie Physique, Collège de France, 11 Place Marcellin Berthelot, 75231 Paris Cedex 05, France. 